сучасного дошкільного навчального закладу : автореф. дис. на здобуття наук. ступеня канд. пед. наук : 13.00.06 / Олена Вікторівна Янко. - Луганськ, 2009. - 20 с.

УДК 811.111(07):378.147

О. В. Гладка,

кандидат пед. наук, доиент,

Криворізький педагогічний інститут

ДВНЗ «Криворізький наиіональний університет»

\title{
АКТИВІЗАЦІЯ ПІЗНАВАЛЬНОЇ ДІЯЛЬНОСТІ МАЙБУТНІХ УЧИТЕЛІВ У ПРОЦЕСІ ВИВЧЕННЯ ІНОЗЕМНОЇ МОВИ
}

Гладка О.В. Активізація пізнавальної діяльності майбутніх учителів у процесі вивчення іноземної мови.

У статті доведено необхідність активізації пізнавальної діяльності майбутніх учителів у процесі вивчення іноземної мови та запропоновано найбільш ефективні сучасні методи, які сприяють успішному розв'язанню цього завдання.

Ключові слова: пізнавальна діяльність, активізація, майбутній учитель, метод.

Гладкая Е. В. Активизация познавательной деятельности будущих учителей в процессе изучения иностранного языка.

В статье доказана необходимость активизации познавательной деятельности будущих учителей в процессе изучения иностранного языка и предложены наиболее эффективные современные методы, способствующие успешному решению данной задачи.

Ключевые слова: познавательная деятельность, активизация, будущий учитель, метод.

Hladka O. V. Activation of future teachers' cognitive activities in the process of learning foreign languages.

In the article the necessity of activation of future teachers' cognitive activities in the process of learning foreign languages is proved. The most effective modern methods favoring the successful solution of the given task are suggested.

Key words: cognitive activities, activation, future teacher, method.

Інтеграція України до Свропейської спільноти, приєднання вітчизняної системи вищої освіти до Болонської декларації, орієнтація на Загальноєвропейські Рекомендації з мовної освіти [2] та пріоритетні напрямки «Національної доктрини розвитку освіти в Україні у XXI столітті» [5] передбачають зацікавленість інформаційного суспільства в особистостях, які володіють іноземною мовою, здатні до творчої праці, професійного розвитку, самостійної й активної діяльності, прийняття рішень, адаптації до мінливих умов сьогодення.

Незважаючи на впровадження технології особистісно-зорієнтованого навчання та необхідність реформ, освітня практика в педагогічних ВНЗ все ще спрямована на передачу максимального обсягу знань, недооцінює розвиток особистості тих, хто навчається, не забезпечує професійну успішність майбутніх учителів.

Розв'язання цієї проблеми - у цілеспрямованій активізації пізнавальної діяльності студентів, що сприяє їх саморозвитку, самореалізації, досягненню високого рівня професіоналізму, озброює їх умінням засвоювати новий матеріал, вчитися впродовж життя, успішно передавати знання і досвід наступним поколінням.

Питанням формування та активізації пізнавальної діяльності студентів в останні роки опікувалися С. Абрамов, С. Вахрушева, Е. Дмитриева, І. Засядько, Т. Квач, Л. Конопляник, Г. Кулагіна, Ю. Насонова, О. Олексюк, Б. Палмер, I. Степанова, О. Шишкова, Г. Шумахер. Однак, у теорії і практиці вищої педагогічної освіти недостатньо вивченою залишається проблема активізації пізнавальної діяльності майбутніх учителів у процесі вивчення іноземної мови. 
Meта статmi - дослідити необхідність активізації пізнавальної діяльності майбутніх учителів у процесі вивчення іноземної мови та запропонувати методи і прийоми для успішної реалізації поставлених завдань.

Робота вчителя - це постійний пошук нових рішень, творчих підходів, виходу зі складних педагогічних ситуацій. У цьому аспекті неможливо говорити про раз і назавжди отримані знання й відповіді. Лише щоденне самовдосконалення, творчий підхід формують справжнього вчителя-професіонала.

За результатами анкетування, проведеного серед студентів першого курсу факультету іноземних мов Криворізького педагогічного інституту ДВНЗ «Криворізький національний університет», було встановлено, що $84 \%$ респондентів не відчувають необхідності та бажання кропіткої самостійної роботи над оволодінням іноземною мовою. Переважна більшість (60\%) опитаних студентів уважає, що завдання викладача полягає в тому, щоб навчити їх іншомовного матеріалу, озброїти вміннями та навичками, необхідними для вільного спілкування іноземною мовою. Однак, власне себе вони позиціонують як об'єкт навчального процесу, виключаючи тим самим для себе необхідність пізнавальної активності, яка є невід'ємою складовою як успішного опанування іноземною мовою, так i формування професійної компетентності майбутнього педагога.

Грунтуючись на результатах анкетування, можна констатувати існування нагальної потреби пошуку сучасних методів і прийомів, які б забезпечували високу активність студентів у навчальному пізнанні, і відтак, сприяли активізації пізнавальної діяльності майбутніх учителів іноземної мови.

Під «активізацією пізнавальної діяльності» розуміють підвищення рівня усвідомленого пізнання об’єктивно-реальних закономірностей у процесі навчання.

Поміж великої кількості сучасних загальнопедагогічних та методичних прийомів ми розглянемо лише ті, які дійсно сприяють активізації пізнавальної діяльності майбутніх учителів в процесі вивчення іноземної мови; форми і зміст яких дозволяють формувати поряд із комунікативною компетенцією, окремі комунікативні та інтелектуальні вміння, що в сукупності складають уміння критичного мислення: метод дискусій; метод рольових ігор; метод проектів; використання мультимедійних (комп’ютерних) технологій.

Проблемний виклад матеріалу сприяє підвищенню ефективності процесу навчання, оскільки це стимулює пізнавальну діяльність, самостійний пошук інформації та прагнення до аналізу та узагальнень [1, с. 4]. Метод дискусій, як один із методів проблемного навчання, дозволяє органічно інтегрувати знання студентів з різних галузей у розв'язанні проблеми, надає можливість використовувати мовні знання, вміння та навички на практиці.

Засвоєння норм раціонального мовного спілкування, правил ведення дискусії сприяє формуванню відповідального ставлення до мовлення, що є однією з найважливіших вимог до сучасного педагога-професіонала.

На жаль, багато вчителів іноземної мови нині не володіють правилами ведення дискусії, вважаючи, що будь-яку розмову, яка складається 3 кількох реплік, можна вважати дискусією.

Характерними рисами методу дискусій є: групова робота учасників; активне спілкування учасників у процесі роботи; вербальне спілкування як форма взаємодії; обмін думками, який відбувається за регламентом, але на основі самоорганізації учасників; спрямованість на досягнення навчальної мети [4].

У структурі заняття, побудованого на основі методу дискусій, можна виокремити такі етапи:

1. Підготовка до дискусії. Визначення теми (предмета) обговорення, мети, вибір головуючого, розподіл ролей (секретаря, комісії, експертів). Вибір теми дискусії - одне 3 найважливіших завдань, які стоять перед групою, що здійснює підготовку дискусії. Бажано, щоб тема була пов'язана з актуальними проблемами сучасності і знаходилася у сфері компетентності учасників. Для вибору теми в групі можна використовувати прийом 
«Мозкового штурму» (Brainstorming), під час якого учасникам обговорення необхідно висловлювати якомога більше варіантів, зокрема незвичайних і навіть фантастичних. Потім із запропонованих ідей відбираються найбільш цікаві для подальшого обговорення.

2. Проведення дискусії. Виступи учасників. Обговорення проекту рішення.

3. Підведення підсумків. Обговорення й оцінка проведеної дискусії. Планування наступних дискусій.

У ВНЗ звертання до цього методу зумовлено тим, що він дає можливість перенести акцент 3 лінгвістичного аспекту на змістовий, досліджувати і розв'язувати проблему іноземною мовою. Оскільки для використання цього методу передбачається наявність певних мовленнєвих знань, умінь та навичок, то вважається доцільним будувати навчальні цикли згідно з рівнем мовленнєвої підготовки поетапно, спочатку формуючи базові вміння міркування, аргументації за допомогою методу дискусії. Потім на цій основі необхідно розвивати активну позицію студентів у реалізації соціальних ролей за допомогою рольових ігор, і нарешті, за допомогою методу проектів досягти найвищого ступеня автономності, того, хто навчається, в організації власної діяльності.

Рольові ігри найчастіше грунтуються на ситуаціях з реального життя, але учасникам цього методу активної навчальної діяльності надається опис ролі, яку вони повинні виконати, і студенти розв'язують проблему відповідно до своєї ролі.

Використання рольових ігор має свої переваги, оскільки студент, виконуючи роль, відмежовує себе від предмета спілкування, обирає позиції та висловлює думки, які б, можливо, не наважився висловити від свого імені. Окрім того, у рольовій грі передбачається кілька рівнів діяльності, що забезпечує кожному учаснику посильний для нього інтелектуальний, емоційний і вольовий рівні вияву своїх сил, оскільки студентські групи знаходяться на різних рівнях розвитку. Тому сценарій навчальної рольової гри має бути гнучким, багатоваріативним та багатовекторним під час застосування в групах різного інтелектуального рівня розвитку і підготовленості [3].

Рольова гра вчить студента самостійно приймати рішення, імітує ситуації практичного використання одержаних теоретичних знань, що сприяє активізації пізнавальної діяльності, підвищенню мотивації до навчання, розвитку професійних інтересів.

Ще одним методом навчання, спрямованим на активізацію пізнавальної діяльності майбутніх учителів у процесі вивчення іноземної мови, є метод проектів.

Проект цінний тим, що в ході його виконання студенти вчаться самостійно здобувати інформацію, отримуючи знання й досвід пізнавальної й навчальної діяльності.

Основними принципами проектної роботи на заняттях з іноземної мови є:

1. Проблемність. Визначення й розв'язання актуальних проблем самими студентами це спонукальний мотив для інтелектуальної діяльності, яка $\epsilon$ необхідною умовою активізації навчальної діяльності.

2. Варіативність. Студентові надається повна самостійність під час роботи над проектом.

3. Когнітивність. Когнітивний підхід у методиці навчання мови передбачає не нав'язувати лінгвістичне знання, а допомогти йому народитись і розвивати його (discovery activities). Саме робота над проектом створює такі потреби, які стимулюють інтерес до навчання, перетворюючи процес вивчення мови на процес відкриття мови.

4. Наявність інтересу до навчального процесу. Як свідчить досвід, студенти засвоюють набагато більший обсяг матеріалу, якщо процес навчання їм подобається.

5. Особистісний чинник. У ході реалізації проекту студенти отримують широкі можливості для того, щоб думати, говорити про себе, свої внутрішні відчуття, інтереси, життєві пріоритети й цінності, що, у свою чергу, активізує спілкування в групі.

Одним із компонентів активізації пізнавальної діяльності майбутніх учителів у процесі вивчення іноземної мови є використання мультимедійних (комп'ютерних) технологій, які надають можливість викладати навчальний матеріал в динаміці, поєднуючи роботу 3 
текстом і візуальну інформативність екрану. Передовий педагогічний досвід засвідчує, що кожне заняття з використанням Інтернет-сайтів викликає емоційний підйом.

Особливий інтерес нині викликають PowerPoint presentations, підготовка яких активізує пізнавальну діяльність студента, мотивує його до самостійного отримання знань та розвитку творчих здібностей.

Доцільно зазначити, що пошук сучасних методів та прийомів активізації пізнавальної діяльності майбутніх учителів у процесі вивчення іноземної мови нині $є$ однією 3 найважливіших методичних проблем. Використання методу дискусій, методу рольових ігор, методу проектів, мультимедійних технологій на заняттях з іноземної мови сприяє формуванню комунікативної компетенції студентів, розвитку окремих комунікативних, інтелектуальних, творчих здібностей, мотивує до плідної самостійної роботи, надає змогу керувати процесом засвоєння знань, активної участі в колективній та груповій роботі. Таке навчання у вищій педагогічній школі сприяє не тільки плідній роботі студента із засвоєння іноземної мови, а й формує педагога-професіонала, здатного до успішної передачі знань, умінь і навичок володіння мовою майбутнім учням.

\section{Література}

1. Виноградова О.С. Формирование иноязычной коммуникативной компетенции с использованием проблемных методов обучения ИЯ на продвинутом этапе специализированного вуза (на материале английского языка) : автореф. дис. на соискание ученой степени канд. пед. наук / О. С. Виноградова. - Москва, 2003. - 24 с. 2. Загальноєвропейські Рекомендації з мовної освіти : вивчення, викладання, оцінювання / наук. ред. укр. вид. С. Ю. Ніколаєва ; пер. $з$ англ. - К. : Ленвіт, 2003. - 273 с. 3. Конопляник Л. М. Активізація пізнавальної діяльності студентів майбутніх інженерів за допомогою новітніх педагогічних технологій / Л. М. Конопляник // Вісник НТУУ КПІ. Серія: Філософія. Психологія. Педагогіка. - К. : 2005. - Вип. 3 (15). - С. 65-69. 4. Морозова И. Г. Дискуссия как метод проблемного обучения и как средство формирования межкультурной компетенции на занятиях иностранного языка в вузах / И. Г. Морозова // Актуальные проблемы теории и методологии науки о языке. - Санкт-Петербург: ЛГУ им. А. С. Пушкина, 2010. - С. 41-51. 5. Національна доктрина розвитку освіти в Україні у XXI столітті // Освіта України. - 23 квітня 2002 р. - № 33. - С. 2-6.

УДК:370.181

Н. М. Гордій, кандидат. пед.наук, доцент, Глухівський начіональний педагогічний університет імені Олександра Довженка

\section{ВИКОРИСТАННЯ ДИТЯЧӦ̈ ЛІТЕРАТУРИ У ПРОЦЕСІ НАВЧАННЯ ПЕРЕКАЗУВАТИ ТЕКСТИ ДІТЕЙ ДОШКІЛЬНОГО ВІКУ}

Гордій Н. М. Використання дитячої літератури у процесі навчання переказувати тексти дітей дошкільного віку.

У статті розкрито питання розвитку зв'язного мовлення дітей дошкільного віку, обгрунтовано значущість використання літератури для дітей під час навчання переказувати, охарактеризовано показники рівнів розвитку зв'язного мовлення.

Ключові слова: зв'язне мовлення, література для дітей, переказування, мовленнєва компетенція.

Гордий Н. Н. Использование детской литературы в процессе обучения пересказу текстов детей дошкольного возраста.

В статье раскрыт вопрос развития связной речи детей дошкольного возраста, обоснованно значимость использования литературы для детей при обучении пересказывания, охарактеризованы показатели уровней развития речи.

Ключевые слова: связная речь, литература для детей, пересказывание, речевая компетенция.

Gordiy N. M. Using Children's Literature in the process of training retelling of preschool children. 